Andrew Melrose

\title{
Jesus, Judas, Jimi and John: culture, communication, media and art in delightful chaos
}

\author{
Abstract \\ This is a paper about a storytelling journey and a journey in storytelling, through a labyrinth of loose \\ affiliates in culture, communication, media and art, which should be seen as a critically creative and \\ creatively critical adventure that tries to make sense of the delightful chaos that is life in \\ representation.
}

This paper started its life as a joke. Having given me a professorial chair, my university was encouraging me to finally deliver my inaugural address - I had put it off five years. They said, all you need to do to commit is give a catchy title, then write it (simple, huh). And I jokingly replied: what, something like, Jesus, Judas, Jimi and John - a storyteller's version of the 'six degrees of separation'? Perfect, they said, and then I was committed. But when I began to think about it, the idea took flight, Icarus-like: unstable and unsteady at first, but I thought, if I don't fly too close to the sun I may just pull it off. Although that will be up to you, the reader, to judge. I should also say, the idea of six degrees of separation as a title didn't quite fit, for it could have included:

Achilles; Aeschylus; Althusar; Amichai; Armitage; Armstrong; Auster; Bach; Bakhtin; Barbauld; Barrell; Baudrillard; Bauman; Beatles; Benjamin; Best; Bettleheim; Bhabha; Blake; Boulter; Bourdieu; Brighton; Brodsky; Bronte; Brown; Browne; Burns; Byrd; Byron; Calvino; Caravaggio; Cervantes; Chambers; Chicago; Christ; Cohen; Coleridge; Conrad; Cowdenbeath; Dahl; Dalgleish; Dante; Da Vinci; Delacroix; Derrida; Dickens; Dublin; Duffy; Dulwich; Dylan; Earle; Eco; Edinburgh; Eliot; Elvis; Engels; Fauré; Fender; Folon; Foucault; Freud; Gillon; Golding; Gowkshill; Goya; Greene; Griffith; Guy; Harris; Harrison; Hawks; Hebdige; Hegel; Heaney; Hendrix; Hitler; Homer; Hume; Husserl; Inglis; Ingres; Iona; Irigaray; Iscariot; Iser; Jagger; Jameson; Jardine; Jonah; Joyce; Kroll; Kundera; Lacan; Larkin; Lawrence; Lennon; Levi; Lévi-Strauss; Los Angeles; McKenna; MacDiarmid; Marquez; Martin\&Co; Martyn; Marx; Miami; Mitchell; Morgan; Mozart; Muldoon; Murakami; Nwokedi; Pele; Phillips; Picasso; Plato; Porche; Propp; Pullman; Renoir; Richard; Rorty; Rose; Rosen; Roth; Rothko; Rowling; San Gimignano; Shelley; Scotland; Scott; Sophocles; Southpaw; Springsteen; Starr; St. Laurent; Stones; Stuart; Strummer; Tallis; Townsend; Tyler; Vega; Virgil; Waits; Webb; White; Wilde; Williams; Wilson; Winchester; Wright; Yeats; Zappa; Zipes; Žižek ... and I keep adding to this list ...

But that would have been silly. However, I do manage to make some odd links. Mostly flights of fancy, but this is a storytelling journey and a journey in storytelling through a labyrinth of loose affiliates in culture, communication, media and art, which should be seen as a critically creative and creatively critical adventure. It is not the last word on anything (for the destination is forever fluid and chimerical) but continues as a journey through connecting themes.

I can't be alone in this, but at certain points in my life I have felt that the entire world is an enigma; a bucketful of words, musical notes, paintings, pictures and ideas all jumbled up as mixed metaphors, assorted similes, rhythms, rhymes, images, silences as hypothetical postulates (and I love those silences), and of course endless ellipses ... weaving a web of complete incomprehension or, as Jen Webb was to call it, 'delightful chaos', for that is what it is. And when I began writing this I thought I would be able to begin unravelling the chaos, but all I have to give you is a fragment, a glimpse, a trace of an incomplete story that goes on indefinitely. That is where my title for this paper, which was originally a talk, comes from. It comes from a voyage, a journey, a quest to try and collate those fragments, to comprehend and make sense of them, but all I have done thus far is make a connection I am still trying to unravel ... 
But let me start with a story. In December 2006 I was sitting in an airport lounge in New York with my son Dan, waiting for a connection to Miami - yes, I know, we lead such exotic lives, but we plant lots of trees. Anyway, Dan was working on a laptop computer, writing his epic novel and I was rereading a novel. Waiting around for connections isn't such a chore; I like airports. I like the anticipation of travel as well as the cross-cultural-continent-crossing mingle of people carrying stories and ideas to and from somewhere else. Just try to picture that idea if you can: buses, boats, bicycles; cars, trains and planes crisscrossing countries with all of their passengers and crew, carrying stories of some kind: a holiday memory; a business meeting; a chance encounter in a Naples restaurant; a lingering stroll in Paris; a haggled-for bargain in a market in Marrakech; misty eyes in Buddy Guy's.

And they are not all just good stories, of course, though we don't need to dwell on those others here goodness knows there will be time enough in all our lives for them. For the point being made is that we are a storytelling species. Stories define our existence and separate us from the other life forms on this planet of ours. The rich intertextuality of life, that which we all experience daily (in the good, bad and other more mundane times), is part of the narrative that sustains our continuing sense of being in the communities in which we co-exist. Of course being in a busy airport lounge provides a different sense of community, but as a storyteller I never feel disconnected from it. Invariably, when I am in public spaces I pause to look up at those fellow travellers, the constantly changing faces who might form the basis of a character in a story of my own or indeed be a part of my own story. And indeed so it happened.

No sooner had I peeked over the pages of my book than I spied a nun strolling across the concourse. Nothing remarkable in this, of course; nuns fly just like everybody else; except that I noticed she was wearing a pair of kitten heels. I wasn't shocked by her shoes, I was just curious, intrigued even, and I found myself smiling and asking, '... what's the story there, then,' and I was off again. Thinking about story, about story telling and about telling stories in this new and exciting 21 st century. But I was also thinking about making connections, seeing how the world is pieced together, because it's the connections that give us the sense and rationale; it's the connections that make the difference between knowledge and ignorance, between innocence and experience; and indeed, for what it's worth, I believe that seeing those connections stands at the very core of understanding the cultural, communication, media and art representations of us as a species. It is being able to see the other, to connect with the other; for, as Baudrillard says, 'the secret of philosophy may not be to know oneself, nor to know where one is going, but rather to dream what others dream ... to give priority to all determinants from elsewhere' (Baudrillard 1993: 187-88). Though like the nun in kitten heels, and like life itself, the connections are full of paradoxes and surprises. So let me tell you a story of my own.

About fourteen years a practical theologian steeped in the 2000-year-old narrative of biblical history and scholarship, with a day job as a Methodist minister, and a radical literary critic deconstructing texts with a Marxist slant as he ploughed the furrows of a $\mathrm{PhD}$, were on a road trip. And like their fictional counterparts, Cervantes' Don Quixote and Sancho Panza[1] (or their textually intervened counterparts, the priest and the communist in Graham Greene's Monsignor Quixote 1982) - driving an Oldsmobile called Rocinante, of course - they found the trip was about tilting at windmills while weighing up analytical investigations on the very nature of story and storytelling. All the while we were driving south from Orange County, Los Angeles, following the Pacific line down through Southern California, through San Diego and taking the Tijuana crossing into the north-west of Mexico. Like I say, I have led a charmed life.

Not everything disappeared into a Mexican tequila-laced sunshine haze, because it was a journey in which the practical theologian and the radical critic cemented the critical, storytelling rationale behind a re-telling of the New Testament, which was in the process of being written and about to be committed to a series of animation films for worldwide broadcast; video and DVD release. The series was and is still called The story keepers.[2]

The story keepers is a film series that has now been seen by millions and millions and millions of people (estimated at 64 million and still counting), mostly kids, throughout the world, and it is hard to overstate the number of people who have come into contact with it. In its first run on ITV in the UK alone it was watched by 1.4 million people, beating the viewing figures of shows such as Disneyclub. Indeed, it was so successful for ITV they ran it for seven years - even on Christmas Day - which was a great source of joy in our house. It's not every day your film makes the Christmas schedule. And when I Googled it for this paper I was still offered nearly two million hits (1,940,000 to be accurate). But two million - who are these people offering me versions of our work in German, Spanish, Farsi and now Mandarin? I am happy to report that one of my research students who lives in Shanghai told me that The story keepers was on Chinese TV only a few days ago, which I think is pretty remarkable. Though I guess what you also want to know is, do I have a pound for every person who has seen it? ... well, you can't weigh joy in pounds, now, can you; the Egyptians used a feather: 


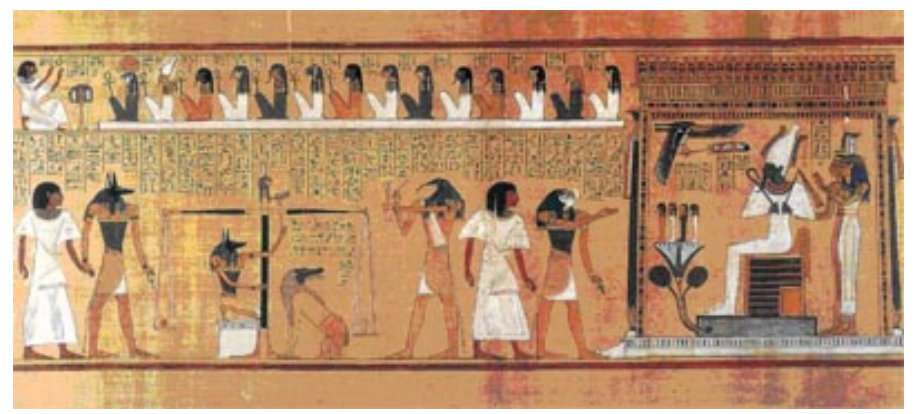

Weighing of the Heart scene, from The Egyptian book of the Dead [3]

But going back to the road trip to Mexico: at the time, getting the rationale behind The story keepers' storytelling delivery right first time was very important for two reasons:

- The first was a mixture of finance and opportunity; it was costing millions of dollars to make and, more importantly, the window to produce such a series only opens once in a generation. It had to be right, there was no second chance, and therefore an opportunity would be lost if not approached with a sound knowledge of what it needed to achieve in terms of the storytelling and theological considerations.

- The second was more important from a theological, storytelling perspective - because it has to be remembered too that it was being researched and written in the period in critical history commonly known as the postmodern[4] and all that went with the ideas around that - death of story; death of metanarratives; storytelling in crisis; as well as which, the inconceivable clamber to jump on the 'end of history' bandwagon set rolling by Francis Fukyama was almost relentless.

Postmodern angst, the end of metanarratives, the end of narrative and the end of history were speedbumps in the road that had to be negotiated if the storytelling exercise was to prove to be academically and theologically viable as well as entertaining enough to withstand such critical scrutiny. Thus, by necessity, it led to a re-appraisal of the storyteller and of storytelling itself in the postmodern age. Hence the Quixotic journey became even more like a version of Graham Greene's Monsignor Quixote as the Marxist critic and the Christian theologian tried to unravel what exactly it was they were trying to accomplish - and, like the title of this paper, it took a roundabout route because it had to address modernism and postmodernism and textual intervention in that debate and in storytelling and indeed in how it related to culture, communication, media and art in an original framework.

In 1936, Walter Benjamin had already pre-dated most postmodern ideas on the death of story by writing that:

Familiar though his name may be to us, the storyteller in his living immediacy is by no means a present force. He has already become something remote from us and something that is getting even more distant. (Benjamin 1973: 83)

I have used this quotation before, but Benjamin's words are prophetic, and to some extent I agree with them. The remoteness of the storyteller in this age of changing media, with limitless access to the world wide web, is important to the crisis storytelling faces today, and indeed that we faced that day in Mexico. Because let's be honest, anyone can be a storyteller now, posting everything and anything electronically through blogs, Facebook, YouTube, etc. There is no limit to this stuff either - indeed I have a blog of my own that no one reads. However, when Benjamin went on to say, 'the art of storytelling is coming to an end,' foreshadowing the doom-laden message of the postmodern debate that was to ensue, I believed he was wrong and set out to prove it in a practical example. But I will dwell on this point just a little longer. Following on from Benjamin's prophecy on the death of storytelling, Jean Baudrillard argued that:

the commodity form is the first great medium of the modern world. But the message that the objects deliver through it is already extremely simplified, and it is always the same: their exchange value. Thus at bottom the message already no longer exists; it is the medium that imposes itself in its pure circulation.

(Baudrillard 1985: 131)

What is the 'message' Baudrillard refers to, if not the story? This idea has a common thread. Jack Zipes in a book on the 'troublesome success of children's literature' wrote in a similar fashion, saying:

In contemporary Western society we are not exactly suffering from a shortage of storytellers and stories. Every day we are inundated by one tale after another on 
TV and radio ... over the World Wide Web. But despite this deluge, something is missing ... we have lost the gift ... of using the power of story to share wisdom and build a meaningful sense of community. (Zipes 2002: 127)

It is a message that rolls Benjamin's and Baudrillard's ideas into one while still plying the 'death of narrative' tale. It is also one Zipes is keen to repeat, since much of his work is on the commodification of stories and the way they are used to hook children as consumers and, in particular, to control their aesthetic interests and consumer tastes. And yet I am still troubled by this idea.

Late in his story about Tomas, the ghosted voice of Milan Kundera's narrator in The unbearable lightness of being (1984) confesses to being the writer and staring back at his characters, back to when he first saw them as a shadow or a silhouette in the window, back to the point before he taught them how to speak, and I always found it to be a very affecting part of the novel. As I have written elsewhere:

To witness a performance, read a book, watch a film, is to see the world presented anew. But to write such a story is to nurture the experience about to be presented and it is at this point that the authentic mark of the story must be stamped. (Melrose 2002a: 21-22)

Kundera was taking himself and his reader back to this point of his story, back to the point when it had barely started. For every story has a point of conception, a point when the story evolves and then begins to speak. As Claude Lévi-Strauss says, 'a book on myths is itself a kind of myth' (Lévi-Strauss 1983: 6); likewise, a book on science can be scientific and a book on theology can be theological, but no matter what, every book is underpinned by a story. It may be written in order to help us identify, observe and address polemical positions, debates and controversial ideas - like the origin of species, queer theology or environmental geochemistry or, in the case of this paper, connections in culture, communication, media and art - but by necessity a bridge has to be built between the speaker and the audience; between the author and the reader; between the writer and the critic. A story is told so that they who are on the receiving end might see the connections. A book, a talk, a paper like this (that was a lecture) says: I have an idea, this is the story, you will hear it as I speak - this is not a story coming to an end, it has only just begun. It has no exchange value, no commodity form and thus the message is greater than the mere circulation.

When we were writing The story keepers we knew this to be the case. The story was not being developed as commodity but as artistic representation in the age of fast culture, communication and media. But we also knew something else: we were some 2000 years away from the oral source of the stories we were about to translate, re-tell and commit to film. And this in itself is still problematic for, as Walter Benjamin has indicated, 'Translation passes through a continua of transformation, not abstract ideas of identity and similarity' (Benjamin 1996: 70).[5] That which is foreign to the original, if only the difference between the storyteller's performance, historical, cultural, racial or otherwise, erodes the original's structures of reference and discourse (Derrida 1967). Here we were, a couple of white middle class guys from the UK, driving through Northern Mexico, trying to re-write the book; trying to rationalise then tell an authentic story which, according to at least the last 100 years of Biblical scholarship, originated as an oral, actual witness account. And we had to try to do this without imposing an empirical, imperial, colonial, gendered or any other preferred mark on it - at least as far as we could avoid it. Not easy, when you are, indeed, two white middle class guys travelling in style, faced with the imperfect traces and limitless horizons of historical memory (Derrida 1967).

And then it became clear to me; the key was in the idea of oral dissemination. What existed long before the theology and exist still are stories told by men and women who, during the dark days of persecution, kept their stories alive and passed them down to us in the form in which we now have them - hence story keeping. An important consideration in this was the advance of time. But it's also important for me to say here, I am not a theologian, nor do I necessarily subscribe to any particular faith; what interests me is the story and stories as they exist and, most importantly, have existed over a wide reaching idea of our culture and representational art. We had to address those stories via the 'experience' of 2000 years of storytelling, to make sure the baton we were taking up kept us in the same race. A 2000-year-old storytelling 'experience' had also to be addressed. Of course, therein too rested another major problem - how does one write experience? Because to raise the question of writing experience is to question narrative itself, for it invites reflection on the very nature of culture and humanity.[6]

Scholars agree it is not possible to 'write' the life of Jesus in any chronological sense (Melrose 2002b). As storytellers, we felt that however well scripted, it would be inappropriate to try and just omnisciently 'tell' the life of Jesus or even a selection of favourite stories because that is not the way we, any of us, received those stories ourselves. That is not the way we were 'shown' the story. It is the 
subtle difference between showing and telling and why the difference matters - it is all about making the connections. Let me explain this.

When referring to such stories, look at your own experience. I 'experienced' The new testament stories before I 'knew' them, in any critical, religious or theological sense. As a child of western culture, the stories are part of my own life story. I'm not here alluding to religious experience - that is another issue - but to a cognitive and cultural experience in my own social development. For example, as a child I lived the stories through events. Christmas day, Easter Sunday, Good Friday, Shrove Tuesday, my sister's christening, my aunt's wedding, my school nativity, Sunday School, school assembly, the cub scouts, gift giving, egg rolling, funeral services and so on. It is through such mediums that a story experience is nurtured and developed. Even as a non-theologian I realised how much I knew and then understood - I could make the connections. Then when we began creating The story keepers we also began to realise how the cultural event and the 'experience' of a story lent itself to its lasting impression. It was this experience that we felt any film series with lasting credibility had to capture, especially for stories to retain the authentic experience they had carried for 2000 years. It was time for a bold and imaginative televisual approach.

All too often the problem with this brainstorming process is treating the story with too much reverence. How many times do we hear the revelation that the film wasn't as good as the book? So because of its cultural veneration we decided not to film the book (the Bible). We decided that instead of trying to film the New Testament we must tell the story of those who kept the story alive before it was written down. In their stories and part of their story is the fact that they kept alive the stories and story of Jesus. We had to incorporate into their stories the stories that they told and re-told under the threat of persecution, and wrote down, in time, in the form that we now have in the Gospels. That was the story we had to concentrate on. The theologian called it practical theology, an imbedding of story and theological insights into cultural life and experience. The simplest way to do this was to place someone at the scene of first hand experience, when the story was still part of the oral tradition. We named him Ben the Baker.

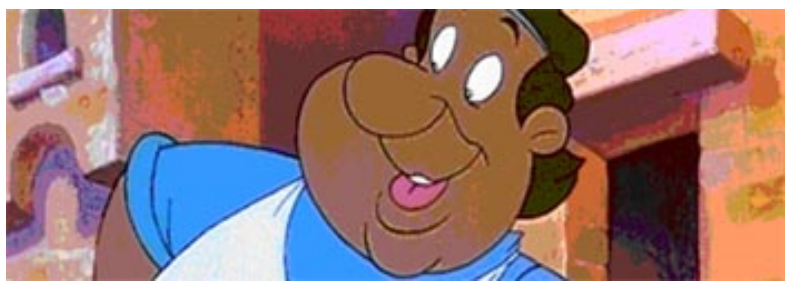

Ben the Baker, The Story Keepers (1998). Picture reproduced courtesy of Shepherd Films, Dublin

In the series, Ben the Baker became a man who told stories to a group of orphans who had lost their parents after Nero's persecution of Christians in AD64.[7] He told them about their parents, their history, their culture and how their life had come this. His role in the film was to help those fictional kids, and thereby the identifying child audience, make the connections.

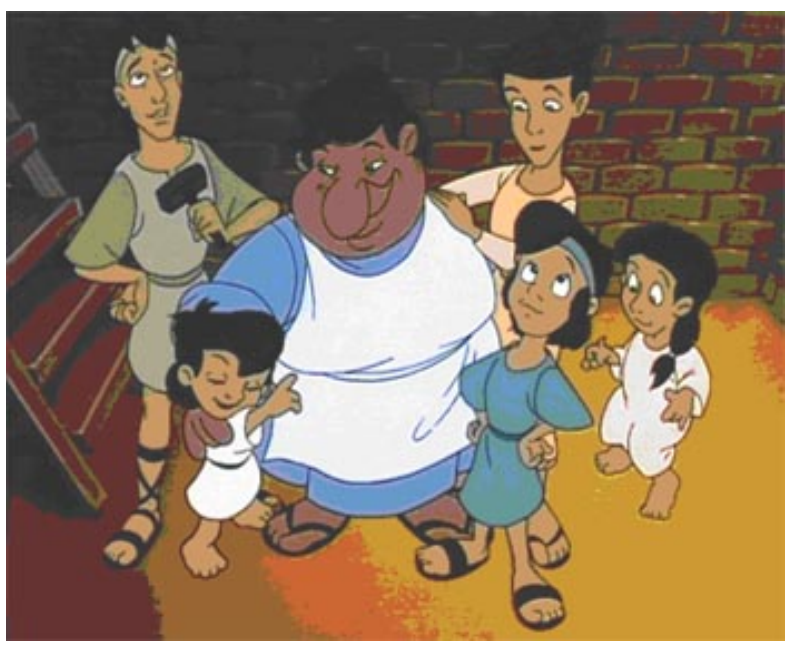

Ben the Baker, Helena and Orphan Family, The story keepers (1998). Picture reproduced courtesy of Shepherd Films, Dublin

AD64 was a good date for this kind of story to be situated; since Nero was in mad power and also, as scholars assure us, the Gospels had still not been written down at this time, it was a period of great flux.

But Ben is more than a fictional character; he is an entire storytelling concept, pioneering a dialogical method of transferring traditional story and experience to today's technological formats, the rationale 
of which provided the basis for its subsequent success and indeed its subsequent imitators

Our storyteller, Ben the Baker, was written as a first generation Christian. Someone who lived in an age of oral tradition, transmitting the story down the historical line until it eventually came to be written down. And we created him in an attempt to circumvent the problem of 'experience' I have just highlighted. Of course, we had absolutely no idea what it was like to have been a first generation Christian. But I do know what it is like to transmit a story I had experienced. So, armed with as much historical and cultural evidence as could be carried, Ben was first of all created as a character who was not only 'keeping' the story. He was written as having been part of it; he was written as having lived the experience first hand, and then, having formulated it as experience, he survived to keep it as a story before passing it on. Let me explain how this was approached by giving an example.

In The story keepers, Ben the Baker is a figure who is represented as grasping the origin of a story that has no real precedent or historical thread to it. We did this by taking him to a version of what might have happened in the story that has come to be known as the feeding of the multitude - or indeed the feeding of the five thousand. In conversation, the story that was incorporated into the first episode of the series went something like this:

one day, Ben and his father were working in his father's bakery. Some neighbours came in and said we are off to hear a Galilean storyteller called Jesus. Why don't you come along? His father was too busy baking bread to go, but he sent young Ben along, giving him some bread for the journey and to sell on the way ... by the time he got to the edge of the lake, young Ben had only five barley loaves left. (Melrose 2002b)

The immediate reference to the five barley loaves helps us to make the link to the story about to unfold. I am not, here, saying Ben was the character who took the bread to the mountain; that is a historical fact too far and there is no supporting evidence. But for the Mark story to be credible, someone had to take that bread. Why not a baker's son who had both bread and time to spare? It seemed reasonable to suggest this might have happened while allowing the reader/viewer to make the connection for him/herself. Indeed we could speculate in similar circumstances on the two fishes and the young baker could just as easily have been Finn the Fisherman's son, for the same story to resonate.

But the placement of Ben in the multitude that the story revolves around is a most significant aspect of the story; especially a story such as the feeding of the multitude. Because the multitude, those who are reported to have attended the event, were also part of the event and thus characters in the story that was unfolding. Not only could the narrative not have taken place without them being there, or indeed without their need to eat; the experience of the story lived on through them.

Taking a very simplistic view of this, it is easy to say the disciples were very smart, in a modern political sense. Who needs a spin doctor when the evidence of 5000 people (or at least a multitude) was staring everyone in the face? But crucially here, the implication is that experience of the story of the event was shared, witnessed and then collaborated by those in attendance, thereby adding credence to the story itself. It was then re-validated, passing all the tests of scrutiny by the attendant multitude, who passed it on to many more as historically the ever-same story. To this extent, therefore, this was not a Jesus story but a story about Jesus; compiled for others by those who, in the face of persecution, had 'experienced' it for themselves.

And it's curious for a non-theologian like me, some ten years further down the line, to see the idea recently confirmed by Dr Rowan Williams, the present Archbishop of Canterbury, when he commented in his Easter 2006 sermon that:

the New Testament is ... the product of a community of people living at great risk and doing so because they sense themselves compelled by a mystery and presence that is completely authoritative for them. (Williams 2006)

The product of the community - their story; he must have seen the series; well, I am entitled to speculate, surely. But of course that's how it worked. If the multitude all told the story to one other person, 5000 people could become, ten, then twenty then... well then we end up 2000 years later with the millions who saw The story keepers on TV - and who knows, the Chinese might now tip that into billions. But they are still the product of that community of people who were first compelled by the story.

But you know, writing the risks to that community was also part of the fun for this storyteller, for in true writing for children style, it also has to be an adventure story. 


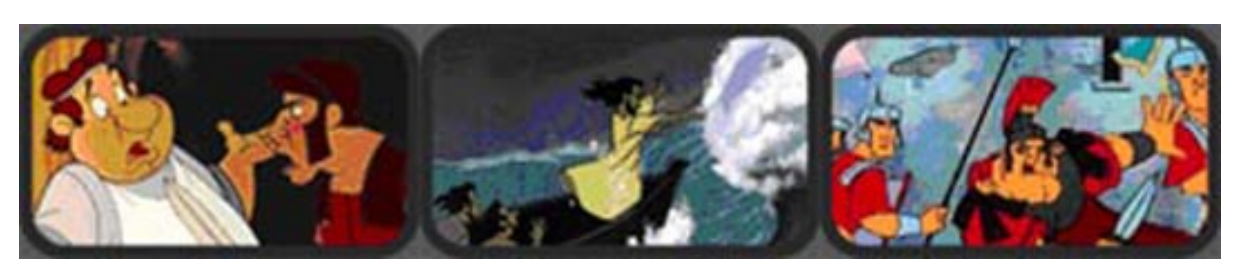

Ben the Baker and Roman Soldier; Jesus Calming the Storm; and Roman Soldiers in scenes from The story keepers (1988)

What we were doing was making the connections. And I urge you to hold onto that thought. But let the last word on this part of the paper rest with another Archbishop, in a personal letter he wrote: 'Storykeepers ... I warmly commend the series.'[8] Dr George Carey, Archbishop of Canterbury (you wait all day for an Archbishop and then two come along at the same time).

It all sounds very simple, I know; indeed the TV producer reduced it down to 'a nice little wraparound', but that is because in its simplified form it's a story within a story within a story, with neverending ellipses ... each folding into the other, leading on to more and more stories as they are passed down the generations. I could say much more about this but space is short.

Thus, as they drove back across the Mexican border the practical theologian and the Marxist critic, still tilting at windmills, knew they had cracked an academic and theological conundrum facing popular television.

But now, since I asked you to hold onto the making the connections thought, I want to proceed by making some of my own. Like the title of this paper, the connections may seem a little random in a postmodern kind of way but bear with me: they and the postmodern idea are important as I now segue my way to the Judas section of the title.

During Easter 2006, a huge fanfare trumpeted through the world of stories and beyond. It was the announcement in the National Geographic that a new gospel of Judas was going to lift the lid of truth on the story and stories I had just been discussing: we waited with bated breath. Though, like everything I approach in the news, I did so with an open mind. It's not that I don't trust headlines such as: Lost Gospel Revealed; Jesus Asked Judas to Betray Him. It's just that I believe in story as critical enquiry. I like to make the connections - or indeed to see whether such connections exist and how valid the claims they make are. And so it came to pass. Was this new Gospel really about to 'contradict everything we knew about the story we had committed to film'? Or was there something else to consider? Well, there is always something else to consider.

The issues around this new gospel are well trammelled by now and the most concise academic explanation I have read is in a short article by Simon Gathercole from the University of Aberdeen. In a press comment preceding his article he is reported as commenting that the Gospel of Judas was written as though someone were to produce a document purporting to be a diary of Queen Victoria, in which she was discussing The Lord of the Rings and the songs on her iPod. Tom Wright, the Bishop of Durham, goes on to reveal that this point was strikingly confirmed by James M Robinson (the esteemed translator of the Nag Hammadi codices) who said:

This new work tells us nothing about the historical Jesus and nothing about the historical Judas. It only tells us what, 100 years later, Gnostics were doing with the story they found in the canonical Gospels. (cited Wright 2006: 27)

Now, even a non-theologian like me can trace the connections in this story. Theologians say the canonical Gospels rely on the oral story as their basis, but that the Gospel of Judas, while materially different from the canonical Gospels, actually relies on those same canonical Gospels as its source material. Which tells us more about the Gnostics who adapted this written-down version than the first generation Christians who told them orally in the first place.

Now of course I am trying to summarise 2000 years of theological expertise here, and it's essentially too complex to be done like this. But what I am interested in is the story of the story; and the idea that in some sense it begins to suggest itself to the ideas of pastiche and parody well before the ideas of postmodernity were even thought of (we can hardly call the Gnostics postmodern). Indeed, it becomes a case of story-engineering - hagiographies are famously of this type - and while the Gospel of Judas has that tone to it, biography is as much about the biographer as about the subject: hence the theological conclusion that the Gospel of Judas tells us more about the Gnostics who wrote it rather than about the subject. But this alerts us to the fact that we have continually to intervene in stories being told to us, because the intervention is a continuing theme in keeping stories alive. It's not easy because, as we can see with the Judas intervention, and indeed the constant dubious sources of internet information, the problem of maintaining authenticity persists everywhere we look. And this 'maintaining authenticity' is at the very core of this paper, where modernism still challenges the postmodern idea: the cause is not lost, as I will now explain. 
There are other ways in which I can demonstrate this because there are other ways to tell a story. In art, for example, there is a current debate that asks the question: is Picasso's Les Femmes d'Alger a pastiche or parody of Delacroix's painting of the same name, or something other? Picasso painted fifteen variations of Les Femmes d'Alger, and 44 variations of Las Meninas by Velazquez, so it wasn't just a whim on his part. Indeed there is a wonderful slide show on the New York Times website, which shows Picasso's engagement with other art masters in a Parisian exhibition entitled Picasso et les maîtres (2008),[9] which can be accessed here

http://www.nytimes.com/slideshow/2008/10/27/arts/20081027_PICASSO_SLIDESHOW_index.html. The narrative accompanying the slide show runs counter to the claims I am making here, but it does help to contextualise the debate.

The well-respected art critic John Berger has said, 'the majority of Picasso's important late works are variations on themes borrowed from other painters ... no more than exercises in painting' (Berger 1972: 183). Is this really the case? Just as I am not a theologian, I am not an art historian either; but Berger's analysis worries me. Because is Picasso's painting not a re-interpretation, a variation on a theme rather than mimicry: as Picasso himself said, 'I am a Spaniard, just like a torero takes his bull through all kinds of passes, I like to take my pictures through all kinds of variations' (cited Time 1957: 84). Of course, critical analysis can be very subjective, but it seems to me that Picasso's 'variations' and an increasing obsession with art history in his late years was not an exercise, and nor was it about just honouring the past masters through parody, pastiche or plain imitation, but is a modernist, textual intervention. As Terry Eagleton was to reveal so succinctly:

parody of a sort is not wholly alien to the culture of postmodernism, though it is not one of which it could be said to be particularly conscious. What is parodied by postmodernist culture, with its dissolution of art into the prevailing forms of commodity production, is nothing less than the revolutionary art of the twentiethcentury avant garde. It is as though postmodernism is among other things a sick joke at the expense of such revolutionary avant-gardism, one of whose major impulses, as Peter Bürger has convincingly argued in his Theory of the AvantGarde, was to dismantle the institutional autonomy of art, erase the frontiers between culture and political society and return aesthetic production to its humble, unprivileged place within social practices as a whole. (Eagleton 1985: 60)

I suggest it was an attempt by Picasso to understand what art is and is a 'return [of] aesthetic production to its humble, unprivileged place within social practices as a whole'.[10] Indeed these pictures not only reveal Picasso the artist, but also Picasso making connections and a critically creative and creatively critical engagement with a rich artistic past of which he can be entitled to be called part.

That's what we tried to do with The story keepers and indeed what Graham Greene did with his novel Monsignor Quixote that intervened in Don Quixote. It's not like a Gospel of Judas, 'changing a story', but a 'story of ongoing engagement' with the original story. Like the late work of Picasso, it's the story of a self-conscious narrative, experimenting with form and process but still being shown to be connected to older stories and art forms from whence it came as they are taken forward. As Jacques Derrida has said, 'this future, this beyond, is not another time, a day after history. It is present at the heart of experience. Present not as a total presence but as a trace' (Derrida 1967: 95).

Thus, it is not postmodern pastiche, nor modernism functioning as a rejection of earlier forms of expression, but modernism acknowledging its historical antecedents in creating something new. The artistic narrative, the story, is surely one about connecting the experience of past times for a new audience. This is not an end of history or a death of the story and storyteller but new ways of adapting to ever increasing demands of delivery - which I will now address further.

There have been many instances of this artistic intervention elsewhere, and from biblical narratives through modern art we can move into popular culture while still making the connections. Let's take this idea a step further. It is purely coincidental but at the same time that National Geographic were running their piece of the Gospel of Judas, the BBC News Magazine were running an article on the Devil's Music and talking about a new film about the so-called Devil's Interval, a musical phenomenon suppressed by the Church in the Middle Ages, that linked the music of Black Sabbath with Wagner's Gotterdammerung, West Side story and the theme tune to the Simpsons. All of them, it said, rely on tritones, a musical interval that spans three whole tones, like the diminished fifth or augmented fourth.

Now I am not a theologian, art critic or a musicologist either (quelle surprise; neither do I speak much French) but this devil's interval, the gap between two notes played in succession or simultaneously, was branded Diabolus in Musica or the Devil's Interval by medieval musicians. A rich mythology has grown up around this idea. Many believe that the Church wanted to eradicate the sounds from its 
music because it invoked sexual feelings, or because it was genuinely the work of the Devil. Such devilish examples including:

- Beethoven's Fidelio

- Wagner's Gotterdammerung

- Elgar's Dream of Gerontius

- Mussorgsky's Night on Bare Mountain

- West Side story's Maria

- Simpsons theme tune

Indeed, wasn't it Woody Allen who said, 'Every time I hear Wagner I think about invading Poland'? Well no wonder, you old devil you. Anyway a connecting theme was being run through the internet as recently as last Christmas when Alexandra Burke, singing Leonard Cohen's Hallelujah,[11] won the wonderful X Factor 2008. The nonsense surrounding the lyrics in the press and electronic media was great reading where their meaning was dissected and debated and scrutinised. But let me tell you some thoughts I had; here are the words:

I've heard there was a secret chord

That David played, and it pleased the Lord

But you don't really care for music, do you?

Well, it goes like this, the fourth, the fifth

The minor fall, the major lift

The baffled king composing Hallelujah ...

The fourth, the fifth: is this the Devil's Interval or David's secret chord? Well we can surely see the irony in this Biblical connection, can't we? Hallelujah to that. But such stuff is the fodder for the world wide web information overload. There is a lot of internet rubbish lined up with serious biblical scholarship, art history, cultural theory and musicology in all of this kind of stuff, as you would expect. As long as we can tell a story, we can all set ourselves up as experts; it's not hard.

But once again it's all about intervening to make connections, it's about separating scholarship from a twittering and wittering culture, where everyone has an immediate opinion and Wikipedia, the free encyclopedia, at the end of their fingers. Stories are there to be critiqued and investigated. But this musical part of my talk brings another character from my title into the story frame, as we move from Biblical narrative into high art then popular culture - see how we do those segue ways? It's a storytelling trick.

Jimi Hendrix was a guitar player in the blues tradition, until, that is, he began making his own Picasso-like variations which allowed him to take traditional blues forward. And this leads us back to the devil's music idea, and to musical tritones. Like David, Jimi too had a chord, and it has been said that so ubiquitous is the 7th sharp 9th sonority in Hendrix's compositions that it has entered the lexicon of guitar vernacular as 'the Hendrix Chord'[12] and that in the particular voicing favoured by Hendrix, it has become a signifier of Hendrix's style of playing. Here is how can be explained:

The voicing where the lineage of the E 7th sharp 9th chord (E7\#9) comprises a root, major third, perfect fifth, minor seventh, and augmented ninth. When spelled enharmonically (the augmented ninth is the equivalent to the minor third) we can see that the chord actually contains the two types of thirds that individually would commonly indicate a chord's major or minor modality. The presence of both pitches results in a certain harmonic ambiguity and a power struggle, of sorts, with both thirds exerting influence over the chords modality are we to hear this as major or minor? Furthermore, the altered dominant seventh chord (of which a 7th \# 9th is but one type) in common practice harmony is traditionally employed as cadential harmony on the fifth scale degree resolving (usually) to the tonic minor. (Aitken [13])

And that is a mouthful, for sure, but there is another way to say this. Click here for a demonstration: http://www.youtube.com/watch?v=_0VrLUKXOt8.[14] Isn't new technology great and isn't this a fantastic addition to the traditional journal paper (which may be developed past this crude film in the future). The man speaking is my doppelgänger, it is not devilish diabolism, though, more like diabolical - but we're back to making connections. How does this connect to Jesus and Judas apart from the Devil idea? It is said that Jimi Hendrix claimed that Purple Haze was originally called Purple Haze/Jesus Saves and that the lyrics had been cut by his manager so they could maintain his wild man of pop image - thus a twist in the story. Nevertheless, the point is that in Picasso-style storytelling terms, this wasn't a re-vamped blues standard but something new - not a tired old blues story but an intervention, a new contribution to the musical story, whatever you may think of electric guitar music. Like Picasso's variations and the films called The story keepers, it was something new built on something old; a textual intervention perhaps, but something new holding the authentic mark 
of being meaningfully connected to the history from whence it came. Not postmodern parody, pastiche, mimicry or even karaoke, but modernism reconnected with its recent, historical past. And while the history of the production is available for scrutiny, as a palimpsest so often exposed that it doesn't even try to hide the influences, these variations that take culture forward are no less relevant to the newness of it. The storyteller is not dead but alive and kicking by constantly revising the means of delivery; the story too lives on.

Of course, my playing Purple Haze is not such a great example; the purists will say I changed some of the notes, and some of those will confirm not for the better, for I was imitating, karaoke style: not improving, improvising or even presenting a variation, just giving a version which has been played and improved upon better than I could - by the Kronos Quintet, for example. But at least I am not claiming it as another Gospel either.

And so we come to John, in my title and I want to tell you another story. The first time I heard John Lennon's album Imagine, I was sitting on the dock of a bay in Oban in the West of Scotland. It was 1971, I was sixteen and instead of studying for my O levels I had been hitchhiking around Scotland, trying to visit as many folk clubs as I could during the Easter break from school. The songs from the album were wafting out of a little yacht moored nearby. The owner of the boat saw me and shouted over; he said he was taking a trip to Iona, did I want to come with him. Well, can you imagine? And to cut a long story short, later that day, with the tape still playing on an 8 track loop - remember them? - we were sailing round the Isle of Mull toward the Sound of Iona when I saw something so unbelievably incredible. Out of nowhere this huge whale rose to the surface alongside us and spouted water high into the air. Can you imagine?

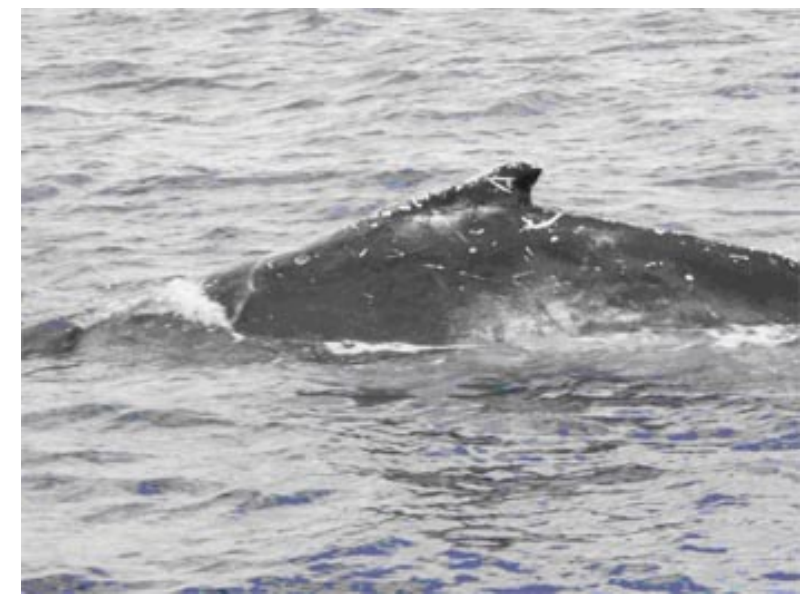

'Whale Back 2'

Image source: Free Nature Pictures www.freenaturepictures.com/whale-pictures.php

When I came to write this story I began thinking nostalgically about that moment and wrote a poem I never write poetry but it was such a poetic moment that it deserved something different. And then in tune with this paper, I wrote it in the language of my birth but it's easy to translate. The poem is called 'Mind Yersel' Jonah' (Melrose 2009: 27):

It wisnae a trawler wi' a net an' a hold fuo o' fish dryin' in salt

Nor Para Handy's puffer puggie fou $\mathrm{o}^{\prime}$

Isla's best malt

It wisnae a twisted wreck wi' a hole in its deck unco fou o' bones an' brine

Nor an auld clipper carrying tea frae the east wi spices an' silks sae fine

Naw this wis somethin' ither somethin' mair muckle a' the gither nowt a mere man wid sail

And ah said, "Mind yersel' Jonah 
for she'll swallie ye hale

yon bloody great whale...

You see, stories go on and on. We started with Jesus, then Judas, then Jimi and John singing Imagine, and yet ended with Jonah, and there is no way I could have planned that. But even as I was writing this the gathering of fragments was still going on, and this was on the BBC website:

The bells of Liverpool's Anglican Cathedral are to ring out to John Lennon's antireligious anthem Imagine. A cathedral spokesman said: 'Allowing Imagine to be pealed on our bells does not mean we agree with the song lyric ... [but] as a cathedral we do not shrink from debate. We recognise the existence of other world views.'

In other words, the story goes on. At the moment, for me anyway, the quest, the journey down this recognition of existence and not shrinking from debate, is the joy of story and storykeeping, for that quest is life itself. What would life be if there were only answers and no questions; only John Lennon's prescribed lyric in Imagine without allowing us space to question and imagine for ourselves; only facts and exclamations without a narrative of experience to address the questions they raise? And for me the underpinning support in the quest for answers is learning - education.

From Reception class through to university and beyond, without education, without the ongoing accumulation of knowledge, that which we connect in institutions and through journals all round the world, our children, our future students, would be chasing chimeras.

Thus, I contend that education, with its variations and ability to drive story forward, continually addressing new media and means of delivering the tale of experience, is the Rosetta Stone of modernity.

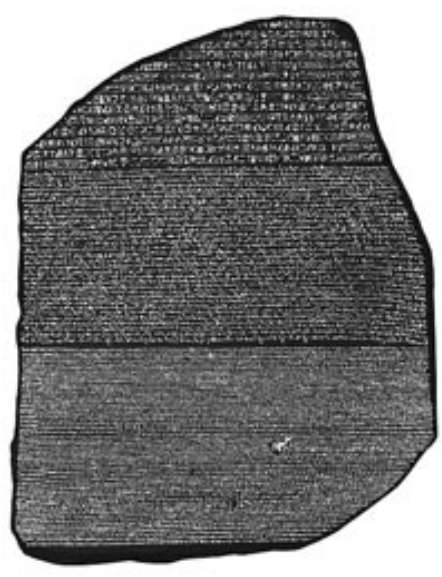

The Rosetta Stone

Image source: the History Department, The American University in Cairo, http://www.aucegypt.edu/academics/dept/hist/about/Pages/default.aspx

It's the key which opens the door to story connections; helping us make sense of the world, from faith to fortune and everything in between, as we grow in experience from children into adults, embracing spiritual, physical, irrational and intellectual uncertainty; it is the key to the future for the world's children and their children's children.

It shouldn't matter what television, the internet, or 24/7 media throw at children if we can keep them in the story loop that is education, so we can teach them to think about the stories that will make up the connections in their lives; stories that define their existence; the rich intertextuality of their lives; the narrative that sustains their continuing sense of being in the communities in which we, all of us, co-exist, so that they may keep questioning the issues that threaten them: poverty, inequality, poor ethics, maltreatment ... If we give up challenging the story, intervening in the narrative, defying closure in the tale, we allow the dictators, tyrants and despots the last word. The world's children deserve better.

This paper was written as my inaugural address as Professor of Children's Writing and for me, that is what writing for children is all about. I have tried to relate this by taking you through a small tour of some fairly minor connecting fragments that make up a trace of my own mind map, because in my own personal quest there are far reaching questions. It has been a bit random but in doing so I hope I have made a connection.

So anyway, going back to that airport in New York, along came this nun in kitten heels, remember her? Did she really exist, was she really real? As I was flicking through some folk-art pictures online I 
came across a picture of a Flying Naughty Nun in Red Heels by Amy Jordan, which you can see here: http://www.flickr.com/photos/folkartblonde/sets/72157594183058059/ Watching her flying, careless and smiling, sums up a creative life for me. Like most things, if she doesn't exist we can just make her up.

Go on, we are tilting at windmills - make your own connection. But in doing so remember this: 'Sentences end with full stops. Stories do not' (Rosen 1985: 38). Stories continue to fly in delightful chaos!

\section{Notes}

1. Miguel de Cervantes Saavedra born in modern Spain (29 September 1547 - 23 April 1616) was a novelist, poet, and playwright, and his magnum opus Don Quixote is often considered the first modern novel. return to text

2. The Story Keepers Series (15 films) written and created by Andrew Melrose and Brian Brown, produced by Shepherd Films (Dublin) and Zondervan (USA), directed by Jimmy T Murakami. return to text

3. Weighing of the Heart scene (Plate III), From the Egyptian book of the Dead 1895 [1240 BCE], The papyrus of Ani (parts translated by EA Wallis Budge and Allen and Faulkner); funerary literature and papyrus which share in common with Biblical authors a belief the heart was the origin of human thought, memory and personality. return to text

4. Writers such as Roland Barthes, Georges Bataille, Jean Baudrillard, Judith Butler, Hélène Cixous, Deleuze and Guattari, Jacques Derrida, Terry Eagleton, Michel Foucault, Jürgen Habermas, Martin Heidegger, Fredric Jameson, Julia Kristeva, Jacques Lacan, Emmanuel Levinas, Jean-François Lyotard and Richard Rorty come mind in creating and developing this debate. return to text

5. I found Homi Bhabha's work on Walter Benjamin's ideas on translation, especially the essay, 'How Newness Enters the World' in The location of culture (Bhabha 1984: 212-35), extremely useful here. return to text

6. I recommend Hayden White's book, The content of the form (1987), on this issue. return to text

7. Death of the parent is the birth of the child; in children's stories, getting rid of parents allows the point of view of the story to be addressed through the child, rather than the parent. Examples of this can be seen far and wide, from Alice in Wonderland to Harry Potter. return to text

8. Dr George Carey, Archbishop of Canterbury, in a private letter to the writers of The story keepers, 1988. return to text

9. Picasso et les maîtres, Galeries Nationales, Grand Palais, 8 octobre 2008 - 2 février 2009, http://www.rmn.fr/Picasso-etles-maitres return to text

10. I am conscious of the Jameson and Eagleton debate on postmodernity; see Fredric Jameson (1984) 'Postmodernism, or the cultural logic of late capitalism', New left review 146, July-August (53-92), and Terry Eagleton (1985) 'Capitalism, modernism and postmodernism', New left review 152, July-August (60-73) on the issues of pastiche and parody. return to text

11. Leonard Cohen $(1984$ Leonard Cohen Stranger Music Incorporated, USA return to text

12. The 'Hendrix Chord' http://paulaitken.com/documents/aitken_hendrix.pdf return to text

13. http://paulaitken.com/documents/aitken_hendrix.pdf; this internet link has disappeared and an effort is being made to contact Paul Aitken. return to text

14. Performance $(\subset)$ Andrew Melrose return to text

\section{List of works cited}

Baudrillard, Jean 1985 'The ecstasy of communication', in Hal Foster (ed), Postmodern culture, London: Pluto Press, 126-34 return to text

Baudrillard, Jean 1993 The transparency of evil - essays on extreme phenomena, London and New York: Verso return to text Benjamin, Walter 1973 Illuminations: essays and reflections, London: Fontana return to text

Benjamin, Walter 1996 'On language as such and the language of man', in Selected writings, Volume 1: 1913-1926 (ed Marcus Bullock and Michael W Jennings), Cambridge MA: Harvard University Press, 62-74 return to text

Berger, John 1972 Ways of seeing, London and New York: Penguin return to text

Bhabha, Homi 1984 The location of culture, Milton Park and New York: Routledge return to text

Derrida, Jacques 1967 Writing and difference (trans Alan Bass), Cambridge MA: University of Chicago Press return to text 
Eagleton, Terry 1985 'Capitalism, modernism and postmodernism', New left review 152, July-August: 60-73 return to text

Fukayama, Francis 1992 The end of history and the last man, London and New York: Penguin

Greene, Graham 1982 Monsignor Quixote, New York: Vintage return to text

Kundera, Milan 1984 The unbearable lightness of being, London: Faber \& Faber return to text

Lévi-Strauss, Claude 1983 The raw and the cooked, Chicago: Chicago University Press return to text

Melrose, Andrew 2002a Write for children, Milton Park and New York: Routledge return to text

Melrose, Andrew 2002b Storykeeping - the story, the child and the word in cultural crisis, Carlyle: Paternoster return to text

Melrose, Andrew 2009 'Mind Yersel' Jonah', first published in Writing in education 49, Autumn: 27 return to text

Rosen, Harold 1985 Stories and meaning, Sheffield, NATE Papers in Education return to text

Time Magazine, 'Picasso: protean genius of modern art', Art section, 27 May: 84, 87

(http://www.time.com/time/magazine/article/0,9171,824904-1,00.html) return to text

White, Hayden 1987 The content of the form, Baltimore: John Hopkins University Press return to text

Williams, Rowan 2006, Sermon for Easter Day, Archbishop of Canterbury Sermons,

http://www.archbishopofcanterbury.org/365 return to text

Wright, Tom 2006 Judas and the Gospel of Jesus, London: SPCK return to text

Zipes, Jack 2002 Sticks and stones - the troublesome success of children's literature from Slovenly Peter to Harry Potter, Milton Park and New York: Routledge return to text

Keywords: culture; communication; media; art; modernism; postmodernism; story

Professor Andrew Melrose has over 150 film, fiction, nonfiction and other writing credits, including The Story Keepers series, broadcast worldwide; he is Professor of Children's Writing at the University of Winchester where he lectures in English and Creative Writing.

\section{TEXT}

Vol 14 No 1 April 2010

http://www.textjournal.com.au

Editors: Nigel Krauth \& Jen Webb

Text@griffith.edu.au 